\title{
Distribution of Apolipoprotein E Phenotypes in Friedreich's Ataxia
}

\author{
D. Bouthillier, ${ }^{(1)}$ A.C. Nestruck, ${ }^{(1)}$ R. Milne,${ }^{(1)}$ C.F. Sing, ${ }^{(2)}$
}

A. Barbeau ${ }^{(1)}$ and J. Davignon ${ }^{(1)}$

\begin{abstract}
Allelic polymorphism at the apolipoprotein $\mathrm{E}$ (apo E) gene locus (alleles $\varepsilon 2, \varepsilon 3$ and $\varepsilon 4$ ) is responsible for the existence of 6 discrete electrophoretic phenotypes of plasma apo E. Since the presence of the $\varepsilon 2$ allele in the genotype tends to be associated with higher triglyceride levels, a study was undertaken to determine if a higher frequency of this allele could account for the presence of higher plasma triglycerides in subsets of patients with Friedreich's Ataxia. The frequency of the apo E phenotypes was determined in 37 subjects with Friedreich's Ataxia and compared with that of 102 normolipidemic and 102 hyperlipidemic individuals. There was no increased prevalence of the E3/2 phenotype and the $\varepsilon 2$ allele in the Friedreich's sample as is found in a hyperlipidemic sample. Furthermore, the $\varepsilon 2$ subset did not have significantly higher plasma triglycerides than the non- $\varepsilon 2$ subset and the hypothesis was rejected. On the other hand, there was a trend for a decreased frequency of the E4/3 phenotype in the Friedreich's sample relative to the hyperlipidemic group but the difference did not reach statistical significance. The apo $\mathrm{E}$ phenotype distribution was also measured in a smaller sample of Charlevoix-Saguenay disease; this led to the discovery of two siblings with the relatively rare E2/2 phenotype and unexpectedly low levels of plasma lipid and lipoprotein concentrations. Plasma apolipoprotein $\mathrm{E}$ concentrations in both diseases were within the normal range except for subjects bearing the E2/2 phenotype.
\end{abstract}

RÉSUMÉ: Le polymorphisme allélique au niveau du gène qui code pour l'apolipoprotéine $\mathrm{E}$ (apo $\mathrm{E}$ ) (allèles $\varepsilon 2$, $\varepsilon 3$ et $\varepsilon 4$ ) est responsable de l'existence de 6 phénotypes de l'apo E plasmatique. Etant donné que la présence de l'allèle $\varepsilon 2$ dans le gémotype favorise l'augmentation des triglycérides plasmatiques, nous avons voulu déterminer si une fréquence accrue de cet allèle pouvait expliquer la présence de triglycérides plus élevés dans des sous-groupes de sujets atteints de l'Ataxie de Friedreich. La fréquence des phénotypes de l'apo $\mathrm{E}$ a été mesurée chez 37 sujets atteints de cette maladie et comparée à celle de 102 sujets normolipidémiques et de 102 sujets hyperlipidémiques. Nous n'avons pas trouvé une prévalence plus élevée du phénotype E3/2 et de l'allèle $\varepsilon 2$ chez les ataxiques, et l'hypothèse a été rejetée. De plus, les triglycérides plasmatiques des porteurs de $\varepsilon 2$ ne sont pas significativement plus hauts que ceux des non-porteurs. Par ailleurs, la fréquence du phénotype E4/3 est réduite, mais pas de façon statistiquement significative, chez les sujets atteints de Friedreich, par rapport aux sujets hyperlipidémiques. Enfin, la répartition des phénotypes d'apo E a aussi été mesurée dans un petit échantillon de patients souffrant de la maladie de Charlevoix-Saguenay. Cette étude a permis de mettre en évidence deux membres d'une même fratrie porteurs du phénotype E2/2 relativement rare. De façon inattendue les lipides et les lipoprotéines étaient remarquablement bas chez ces sujets. Enfin, les concentrations d'apolipoprotéine $\mathrm{E}$ étaient dans les limites de la normale chez les sujets atteints de l'une ou l'autre de ces maladies, sauf pour les porteurs du phénotype E2/2.

Can. J. Neurol. Sci. 1984; 11:626-630

The anomalies of plasma lipids and lipoproteins in Friedreich's Ataxia are relatively discrete and often tend to exhibit a bimodal distribution (Huang et al., 1978, 1980; Davignon et al., 1979; Blache et al., 1982). One consistent finding is the tendency for plasma triglycerides to be higher in the affected subjects than in an age- and sex-matched control group (Huang et al., 1978). This finding has been correlated with lower levels of plasma lipoprotein lipase activity (Blache et al., 1982). Interestingly, a subgroup of Friedreich's Ataxia patients clustered in the low range for both heparin-releasable lipase activities, i.e. lipoprotein lipase and hepatic triglyceride lipase, and this subgroup had the highest plasma triglyceride concentrations.
Apolipoprotein E (apo E), a normal constituent of plasma chylomicrons, very low density lipoproteins (VLDL) and high density lipoproteins (HDL) plays a major role in plasma lipid transport and in the catabolism of triglyceride-rich lipoproteins (Mahley and Innerarity, 1983). Three alleles, $\varepsilon 4, \varepsilon 3$ and $\varepsilon 2$, coding at a single gene locus determine the three major isoforms of this apolipoprotein (E4, E3 and E2) and are responsible for six major apolipoprotein $E$ phenotypes in the population (Utermann et al., 1977; Zannis and Breslow, 1981). Homozygotes for these alleles (phenotypes E4/4, E3/3, E2/2) have only one major circulating isoform, whereas heterozygotes $(E 3 / 2$, $\mathrm{E} 4 / 2, \mathrm{E} 4 / 3$ ) have two. The three predominant isoforms differ

From the Clinical Research Institute of Montreal' and Department of Human Genetics, University of Michigan².

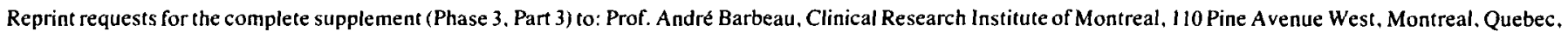
Canada H2W IR7. 
from one another by a single amino acid substitution at either of two sites (residues 112 and 158) on the 299 amino acid chain of the apo E molecule (Weisgraber et al., 1981). Apo E4 has arginine and apo E2 cysteine at both sites, while apo E3 has cysteine at 112 and arginine at 158 . Apo E2 has less affinity for the apo $E$ receptor of liver cell membranes and for the apo $\mathrm{B}, \mathrm{E}$ receptor of peripheral cells than the other two isoforms (Schneider et al., 1981; Mahley and Innerarity, 1983). This in part accounts for the reduced catabolism of triglyceride-rich lipoproteins in familial dysbetalipoproteinemia type III (Gregg et al., 1987), where the E2/2 phenotype is most frequent (Ghiselli et al., 1982a). On the other hand, there is increasing evidence that additional factors are involved in the development of hyperlipidemia associated with the E2/2 phenotype (Rall et al., 1983). Utermann et al. (1979) were the first to report higher triglyceride concentrations in the plasma of normolipidemic subjects with the $\varepsilon 2$ allele. Further, a recent survey conducted in our laboratory demonstrated an enrichment in the $\varepsilon 2$ allele in a lipid clinic population where hypertriglyceridemia was the predominant lipid transport disorder (Davignon et al., 1984). Hence, bearers of the $\varepsilon 2$ allele are most susceptible to developing a hyperlipidemia in response to a second factor.

Because of this increased likelihood of higher plasma triglyceride levels in subjects with the $\varepsilon 2$ allele, we set out to determine whether an unusual distribution of the apo E phenotypes could account for the higher plasma triglyceride levels in subgroups of patients with Friedreich's Ataxia. We also measured plasma apolipoprotein E levels since certain forms of hyperlipidemia are associated with high plasma apo $\mathrm{E}$ concentrations (Curry et al., 1976).

\section{Material AND Methods}

\section{Subjects}

The study was carried out on 37 patients ( 15 males, 22 females) aged 15 to 35 years affected with Friedreich's Ataxia as defined by the criteria of the QCSFA (Barbeau, 1976). Three men and 8 women (25-49 years) with Charlevoix-Saguenay disease (Bouchard et al., 1978), a recessive form of spastic ataxia, were also studied. All patients from the Friedreich's group were in stages III $(n=8)$ or IV $(n=28)$ of their disease according to the functional staging of ataxia described by Pourcher and Barbeau (1980). The Friedreich's group included 16 first-degree relatives from eight different families. The Charlevoix-Saguenay sample included three siblings.

The apo E phenotype distribution of these patients was compared with two population samples (Davignon et al., 1984). The first included 102 subjects taking part in a longitudinal study of HDL-cholesterol levels in a randomly selected cohort of healthy civil servants aged 20 to 59 years. They were recruited mainly within the public services in Ottawa from technical, professional and clerical workers. This work was made possible by the most helpful collaboration of Dr. J. Beare-Rogers, P. Verdier and M. Collins of the Bureau of Nutritional Sciences in Ottawa. Only plasma from individuals with normal lipid levels (cholesterol $\leqslant 240 \mathrm{mg} / \mathrm{dL}$ and triglycerides $\leqslant 150 \mathrm{mg} / \mathrm{dL}$ ) on at least two follow-up visits over several months was examined for apo $E$ phenotype and lipoprotein profile in our laboratory. The second comparison sample was obtained from 102 successive subjects referred to our lipid clinic with hyperlipidemia. The majority $(n=76)$ had elevated triglycerides with a type IV electrophoretic phenotype and a normal plasma cholesterol, 11 had type IIa, 7 type IIb and 4 were classified as type III (Fredrickson et al., 1978).

The major characteristics of the 4 groups of subjects studied, including age and mean plasma lipid and lipoprotein concentrations, are reported in Table 1.

\begin{tabular}{lcccc}
\hline Table 1: Characteristics of the subjects & & \\
\hline \hline & $\begin{array}{c}\text { Normo- } \\
\text { lipidemic } \\
\text { volunteers }\end{array}$ & $\begin{array}{c}\text { Hyper- } \\
\text { lipidemic } \\
\text { subjects }\end{array}$ & $\begin{array}{c}\text { Friedrich's } \\
\text { Ataxia }\end{array}$ & $\begin{array}{c}\text { Charlevoix- } \\
\text { Saguenay }\end{array}$ \\
\hline Number of subjects & 102 & 102 & 37 & 11 \\
Number of males & 55 & 70 & 15 & 2 \\
Age, years, $x \pm$ SD & $36.1 \pm 8.5^{*}$ & $45.9 \pm 12.5$ & $24.3 \pm 5.4$ & $35.6 \pm 11.6$ \\
$\quad$ Range & $(22 \cdot 66)$ & $(14-82)$ & $(15-35)$ & $(17-50)$ \\
Body mass index & $23 \pm 3$ & $28 \pm 5$ & $19 \pm 3$ & $20 \pm 5$ \\
$\quad$ (weight/height ${ }^{2}$ ) & $174 \pm 29$ & $262 \pm 83$ & $161 \pm 36$ & $161 \pm 36$ \\
Cholesterol & & & & $112 \pm 48$ \\
$\quad$ (mg/dL \pm SD) & $74 \pm 30$ & $548 \pm 696$ & $94 \pm 49$ & 110 \\
Triglycerides & $23 \pm 12$ & $98 \pm 89$ & $21 \pm 10$ & $25 \pm 8$ \\
VLDL-cholesterol & $104 \pm 26$ & $132 \pm 65$ & $101 \pm 32$ & $90 \pm 29$ \\
LDL-cholesterol & $47 \pm 12$ & $33 \pm 10$ & $39 \pm 9$ & $45 \pm 9$ \\
HDL-cholesterol & $58 \pm 11^{* *}$ & - & $56 \pm 25$ & $55 \pm 24$ \\
Apolipoprotein E & & & &
\end{tabular}

${ }^{*}$ Mean \pm S.D. Lipids and lipoprotein are given in $\mathrm{mg} / \mathrm{dL}$, apolipoprotein $\mathrm{E}$ in $\mu \mathrm{g} / \mathrm{mL}$.

${ }^{* *}$ Control values in normal subjects $(n=6)$ are those reported by Milne et al. (1981), Plasma apo E was measured in 32 cases of Friedreich's Ataxia and 9 cases of Charlevoix-Saguenay disease.

\section{METhods}

Venous blood for apo E phenotyping and plasma lipid and lipoprotein analyses was drawn in the morning after a 12- to 13-hour fast into tubes containing disodium EDTA (1 mg per $\mathrm{mL}$ of blood). The apo $\mathrm{E}$ phenotype was determined on a washed and delipidized VLDL fraction by isoelectric focusing on polyacrylamide gel using a modification of the method of Warnick et al. (1979) developed in this laboratory (Bouthillier et al., 1982). Plasma total cholesterol (Allain et al., 1974) and triglycerides (Sampson et al., 1975) were measured enzymatically on an autoanalyzer (ABA-100, Abbott Laboratories, Pasadena, CA). Plasma lipoprotein cholesterol (Allain et al., 1974) was measured after separation of the lipoproteins according to the Lipid Research Clinics' protocol (Manual of Laboratory Operations 1974). Plasma apolipoprotein E concentrations were measured by radioimmunoassay using the monoclonal antibody 6C5 (Milne et al., 1981). A chi-square analysis of heterogeneity was carried out to compare the allele and genotype frequencies of the samples.

\section{RESULTS}

The proportion of subjects within each of the six apo $E$ phenotypes as well as the frequency of the three alleles are given in Table 2 for each of the four samples. Initial inspection of the data discloses a relative paucity in the Friedreich's group 
Table 2: Apo E Phenotype and Allelic Frequencies in the Four Samples

\begin{tabular}{lcrrr}
\hline $\begin{array}{l}\text { Phenotype } \\
\text { or allele }\end{array}$ & $\begin{array}{c}\text { Normo- } \\
\text { lipidemics } \\
(\mathbf{n}=102)\end{array}$ & $\begin{array}{c}\text { Hyper- } \\
\text { lipidemics } \\
(\mathbf{n}=102)\end{array}$ & $\begin{array}{c}\text { Friedreich's } \\
\text { Ataxia } \\
(\mathbf{n}=\mathbf{3 7})\end{array}$ & $\begin{array}{c}\text { Charlevoix- } \\
\text { Saguenay } \\
(\mathbf{n}=\mathbf{1 1})\end{array}$ \\
\hline $\mathrm{E} 4 / 4$ & $4(3.9)^{*}$ & $0(0.0)$ & $1(2.7)$ & $0(0.0)$ \\
$\mathrm{E} 3 / 3$ & $63(61.8)$ & $50(49.0)$ & $24(64.9)$ & $5(45.5)$ \\
$\mathrm{E} 2 / 2$ & $2(2.0)$ & $3(2.9)$ & $1(2.7)$ & $2(18.2)$ \\
$\mathrm{E} 4 / 3$ & $21(20.6)$ & $24(23.5)$ & $5(13.5)$ & $0(0.0)$ \\
$\mathrm{E} 3 / 2$ & $10(9.8)$ & $18(17.7)$ & $5(13.5)$ & $3(27.3)$ \\
$\mathrm{E} 4 / 2$ & $2(2.0)$ & $7(6.9)$ & $1(2.7)$ & $1(9.0)$ \\
$\varepsilon 2$ & $16(7.8)$ & $31(15.2)$ & $8(10.8)$ & $8(36.4)$ \\
$\varepsilon 3$ & $157(77.0)$ & $142(69.6)$ & $58(78.4)$ & $13(59.1)$ \\
$\mathrm{E} 4$ & $31(15.2)$ & $31(15.2)$ & $8(10.8)$ & $1(4.5)$ \\
\hline
\end{tabular}

* The number $(n)$ of subjects is given for each phenotype or allele, the percentage is given in parentheses.

of the E4/3 phenotype, the second most frequent phenotype in a normal population. As a consequence, the $\varepsilon 4$ allele frequency in the Friedreich's sample is the lowest of the 3 major groups. On the other hand, there is no enrichment in this group in the E3/2 phenotype and the $\varepsilon 2$ allele is similar to that observed in the lipid clinic sample. In the heterogeneity chi-square analysis, comparison of the Friedreich's sample with either of the other two major groups demonstrates no statistically significant difference at the $5 \%$ level of probability for the $\varepsilon 2$ allele (Table 3 ). As reported elsewhere, the lipid clinic sample differs from the normolipidemic group $\left(\chi^{2}=10.96, p=0.052\right)$ and does show an enrichment in the E3/2 phenotype (Davignon et al., 1984). The lowest $x^{2}$ is obtained for the allele frequencies when the Friedreich and the lipid clinic samples are contrasted. A chi-square analysis failed to detect significant heterogeneity of genotype or allele frequencies between the Friedreich's sample and the normal or hyperlipidemic samples at the $10 \%$ level of probability (Table 3). However, because of the reduced frequency of the E4/3 genotype and the $\varepsilon 4$ allele compared to both normal and hyperlipidemic samples, we chose to partition the chisquare to determine the relative contribution of specific contrasts to the total heterogeneity chi-square. An increase in the $E 3 / 3$ and a decrease in the E4/3 relative frequencies explains $37 \%\left(x^{2}=2.37 p=0.12\right)$ of the total heterogeneity with the Friedreich's sample, and $53 \%\left(x^{2}=0.73 p=0.39\right)$ of the total heterogeneity between the normal and Friedreich's samples. All other contrasts made smaller contributions. By contrast, partitioning of the $\chi^{2}$ for the allelic comparisons reveals that $98 \%(5.41)$ of the total $\chi^{2}(5.54)$ for heterogeneity in allele frequency between normolipidemics and hyperlipidemics is attributable to the contrast of the $\varepsilon 2$ allele with the other alleles combined; a finding which has already been reported (Davignon et al., 1984).

In the Friedreich's group, seven subjects with the $\varepsilon 2$ allele had mean cholesterol and triglyceride levels $( \pm$ SD) of $165 \pm 26$ and $119 \pm 77 \mathrm{mg} / \mathrm{dL}$ respectively, as compared to $158 \pm 36$ and $89 \pm 41 \mathrm{mg} / \mathrm{dL}$ respectively (N.S.) in the remaining 30 subjects. Even after excluding the individuals with triglycerides above $150 \mathrm{mg} / \mathrm{dL}$ (one in the $\varepsilon 2$ subset and 4 in the non- $\varepsilon 2$ subset), the difference in plasma triglycerides was not statistically significant between the two subsets $(92 \pm 34$ vs $78 \pm 30$ ). It is thus unlikely that a difference in apolipoprotein $E$ phenotype distri-
Table 3: Heterogeneity Chi-Square Analysis of the differences between the 3 major samples

\begin{tabular}{lrrr}
\hline \hline & d.f. & $\mathrm{X}^{2}$ & $\mathrm{p}$ \\
\hline Phenotypes & & & \\
$\quad$ Friedreich vs Normal & 5 & 1.37 & 0.93 \\
$\quad$ Friedreich vs Hyperlipidemics & 5 & 6.44 & 0.27 \\
$\quad$ Normal vs Hyperlipidemics & 5 & 10.96 & 0.05 \\
Alleles & & & \\
$\quad$ Friedreich vs Normal & 2 & 1.31 & 0.52 \\
$\quad$ Friedreich vs Hyperlipidemics & 2 & 2.07 & 0.36 \\
$\quad$ Normal vs Hyperlipidemics & 2 & 5.54 & 0.06 \\
\hline
\end{tabular}

bution could entirely account for higher plasma triglyceride levels in subgroups of patients with Friedreich's Ataxia.

The small sample of subjects affected with Charlevoix-Saguenay disease raises some interest because of the presence of two patients with the rare E2/2 phenotype: siblings aged respectively 30 and 29 years. A third sib is a 31-year-old woman with mental deficiency and the E3/2 phenotype. All three are affected with spastic ataxia. This disease had been reported on both sides of the family and, as expected in a recessive disease, neither of the parents was affected. The mother was found to be heterozygote for the $\varepsilon 2$ allele. The results of the lipid and lipoprotein profile are given in Figure 1. Interestingly, both subjects with the E2/2 phenotype had low-normal plasma cholesterol and triglyceride levels and low LDL-cholesterol concentrations. They were non-obese, normoglycemic individuals at stage II of their disease and the low lipid levels could not be attributed to wasting or dietary aberration. The unusual profile of apo $E$ genotype frequencies in this sample may not be significant because the two subjects with the E2/2 phenotype are from the same family and their presence in the sample may well be due to chance. Plasma apo $E$ was measured in only one of these (the 30-year-old E2/2 woman), it was at the upper limit of normal $(84 \mu \mathrm{g} / \mathrm{mL})$. There was also one 23-year-old E2/2 subject in the Friedreich's sample. He had a normal cholesterol $(168 \mathrm{mg} / \mathrm{dL})$ but higher triglycerides $(144 \mathrm{mg} / \mathrm{dL})$ and VLDL-C $(42 \mathrm{mg} / \mathrm{dL}$ ) than the mean of the group. His LDL-C was relatively low $(87 \mathrm{mg} / \mathrm{dL})$ with a normal HDL-C ( $39 \mathrm{mg} / \mathrm{dL})$. He had the highest apo $\mathrm{E}$ level recorded in this study $(134 \mu \mathrm{g} / \mathrm{mL})$ and may be considered to have a mild dysbetalipoproteinemia type III. On the average, the plasma concentrations of apolipoprotein $\mathrm{E}$ in Friedreich's ataxia and Charlevoix-Saguenay disease did not differ from those reported in a sample of normolipidemic healthy volunteers (Table 1).

\section{Discussion AND CONCLUSION}

The reason for the existence of polymorphic forms of apolipoprotein $\mathrm{E}$ is not yet established. The persistence of the less common alleles $(\varepsilon 2, \varepsilon 4)$ in the population could be ascribed either to random genetic drift or to balancing selection. The allele frequency reported for our normolipidemic population is virtually the same as those reported for larger population samples of blood donors (Utermann et al., 1982) or factory employees (Menzel et al., 1983) in Germany.

Higher triglyceride concentrations have been reported in the apo E-D and apo E-ND phenotypes (roughly equivalent to the 


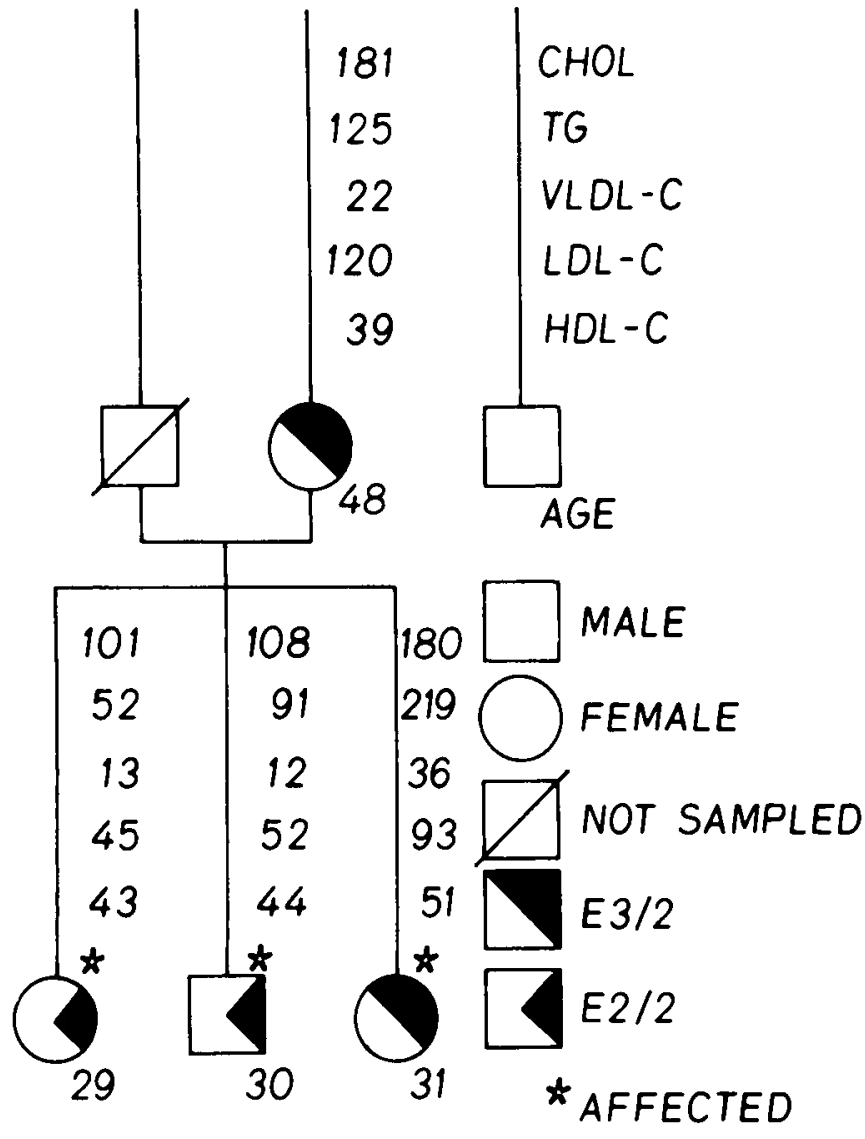

Figure I - Apolipoprotein E phenotypes, plasma cholesterol (CHOL), triglycerides (TG) and cholesterol of very low density (VLDL). low density (LDL) and high density (HDL) lipoproteins in a nuclear family where three siblings are affected with recessive spastic ataxia of CharlevoixSaguenay.

$\mathrm{E} 2 / 2$ and the $\mathrm{E} 3 / 2$ phenotypes in the current nomenclature) by Utermann et al. (1979) and several observations indicate that the presence of the $\varepsilon 2$ allele predisposes to the development of hypertriglyceridemia (Rall et al., 1983; Davignon et al., 1983, 1984). The higher frequency of the $\varepsilon 2$ allele (E3/2 and $E 4 / 2$ phenotypes) in the lipid clinic population where hypertriglyceridemia is prevalent illustrates this point. There is also a trend in the Friedreich's sample towards higher mean triglyceride levels among the bearers of the $\varepsilon 2$ allele. But the relative frequency of this allele and of the E3/2 phenotype is not increased as in the population of hyperlipidemic subjects. Furthermore, the percentage of subjects with the $\varepsilon 2$ allele is not commensurate with the proportion of patients with higher triglyceride levels reported in Friedreich's Ataxia (Huang, 1978). Indeed, less than $20 \%$ of the subjects have the apo E2 isoform and only a small proportion of these have higher triglyceride levels than the bearers of the E3/3 phenotype. Only two subjects with the $\varepsilon 2$ allele had triglyceride levels one standard deviation above the mean for the Friedreich's patients with the E3/3 phenotype ( $89 \pm 38 \mathrm{mg} / \mathrm{dL}, \mathrm{n}=24$ ), although there was a trend towards higher triglycerides among the bearers of the $\varepsilon 2$ allele $(119 \pm 77$ $\mathrm{mg} / \mathrm{dL}, \mathrm{n}=7, \mathrm{t}=1.43 \mathrm{~N}$.S.). Furthermore, the plasma triglycerides were not statistically different between the $\varepsilon 2$ subset $(n=7)$ and the non- $\varepsilon 2$ subset $(n=30)$. The apo $E$ phenotype distribution in the Friedreich's sample is not different from that of the normal population. In Friedreich's Ataxia, subjects with higher triglyceride levels may represent as much as $50 \%$ of the sample (Blache et al., 1982). Thus, our working hypothesis that an increased frequency of the $\varepsilon 2$ allele would account for a subset of subjects with higher triglyceride levels in Friedreich's Ataxia must be rejected.

The relative paucity of the $\varepsilon 4$ allele in the Friedreich's sample if it were to persist in a larger sample size, would be of interest in view of the recent report of an association between mixed hypertriglyceridemia type $\mathrm{V}$ and the $\varepsilon 4$ allele (Ghiselli et al., 1982b).

This is the first report of plasma apolipoprotein $\mathrm{E}$ measurements in Friedreich's ataxia and Charlevoix-Saguenay disease. They were well within the normal range in both conditions except in one case of Friedreich's ataxia with the E2/2 phenotype and a mild dysbetalipoproteinemia type III, and also in one E2/2 woman with Charlevoix-Saguenay disease. This is to be expected since familial type III is known to be associated with higher apo E levels (Curry et al., 1976).

There has been no report so far of an association of particular apolipoprotein $\mathrm{E}$ phenotypes with any neurological disease. This does not mean that apolipoprotein E plays no role in the functioning of the central nervous system since apo $E$ is one of the major apolipoproteins found in the cerebrospinal fluid in man, the other being apo AI (Roheim et al., 1979). Furthermore, a recent report that apolipoprotein $\mathrm{E}$ mRNA is relatively abundant in the brain of rats and monkeys indicates an active synthesis of this lipid transport molecule by the brain (Elshourbagy et al., 1984). The apo E locus is on chromosome 19 in man (Olaisen et al., 1982) and is closely linked to the C3 component of complement. Interestingly, another multifaceted myopathic syndrome with cell membrane abnormalities, myotonic dystrophy, is also closely linked to the $\mathrm{C} 3$ component of complement on chromosome 19 (Eiberq et al., 1981).

Uncommon mutants of apo $E$ alleles have been reported recently where amino acid substitutions occur at sites other than 112 and 158 (Rall et al., 1982; McLean et al., 1983; Gregg et al., 1983). Some of these mutants affect the $\varepsilon 2$ allele, some are related to hyperlipoproteinemic states and others include silent mutations. Our phenotyping technique can detect only mutations which involve a charge shift in the isoform bands such as that of apo E:Bethesda (Gregg et al., 1983). Both the Friedreich and the Charlevoix-Saguenay samples were examined closely for the presence of apo $\mathrm{E}$ : Bethesda or other mutations in the $\mathrm{E} 1$ zone and none were found. The Charlevoix-Saguenay sample was included in this paper because the first two subjects studied had the rare E2/2 phenotype. They are brother and sister and another member of the family has ataxia associated with mental deficiency. Samples from 9 other subjects were obtained to exclude the possibility of a close association of the $\varepsilon 2$ allele with this disease state. It was surprising to find very low lipids and lipoprotein levels in the two E2/2 subjects. The LDLcholesterol of the E2/2 sibling was about half of that of their sister who inherited the E3/2 phenotype. They had a mean LDL-C of $49 \mathrm{mg} / \mathrm{dL}$, slightly lower than the mean for 6 normolipidemic subjects (cholesterol $137 \pm 51$, triglycerides $104 \pm 20 \mathrm{mg} / \mathrm{dL}$ ) (5 males, 1 female, mean age of $22.8 \pm 6.2$ ) with the E2/2 phenotype used for comparison (VLDL-C $30 \pm 9$, LDL-C $63 \pm 48$, HDL-C $48 \pm 22$, pooled data from our experi- 
ence and that of Breslow et al., 1982). This leads us to suspect the presence of a rare mutant of $\varepsilon 2$ which would react almost normally with the apo $\mathrm{B}, \mathrm{E}$ receptor, such as the so-called $\varepsilon 2^{*}$ and $\varepsilon 2^{* *}$ mutants (Rall et al., 1984) and warrants further investigation.

\section{ACKNOWLEDGEMENTS}

This study was supported by grants from the "Association Canadienne de l'Ataxie de Friedreich", the Medical Research Council of Canada (MT-5427), the National Health Research and Development Program (\#6605-2087-52), the National Institutes of Health (HL 24489 and HL 16008) and the Quebec Heart Foundation.

The collaboration of Dr. Joyce Beare-Rogers, Ms Pamela Verdier and Mr. Maurice Collins of the Bureau of Nutritional Sciences of Canada is gratefully acknowledged.

The authors wish to thank Ms Suzanne Paris R.N.. Denise Brossard R.N. and Hélène Mailloux R.N. for their help with the patients, Mr. Michel Tremblay and Louis-Jacques Fortin for their technical assistance and Réjeanne Ouellet for typing the manuscript.

\section{REFERENCES}

Allain CC, Poon LS, Chan FCS, Richmond W, Fu PC (1974) Enzymatic determination of total serum cholesterol. Clin Chem 20:470-475.

Barbeau A (1976) Friedreich's Ataxia 1976. An overview. Can J Neurol Sci 3:389-397.

Blache D, Bouthillier D, Barbeau A, Davignon J (1982) Plasma lipoprotein lipase and hepatic lipase activities in Friedreich's Ataxia. Can J Neurol Sci 9:191-194.

Bouchard JP, Barbeau A. Bouchard R. Bouchard RW (1978) Autosomal recessive spastic ataxia of Charlevoix-Saguenay. Can J Neurol Sci 5:61-69.

Bouthillier D, Sing CF, Davignon J (1983) Apolipoprotein E phenotyping with a single gel method - application to the study of informative matings. J Lipid Res 24:1060-1069.

Breslow JL, Zannis VI, Sangiacomo TB, Third JLHC. Tracy T, Glueck CJ (1982) Studies of familial type III hyperlipoproteinemia using as a genetic marker the apo E phenotype E2/2. J Lipid Res 23:1224-1235.

Curry MD, McConathy WJ, Alaupovic P, Ledford JH, Popovic M (1976) Determination of human apolipoprotein $\mathrm{E}$ by electroimmunoassay. Biochim Biophys Acta 439:413-425.

Davignon J, Huang YS, Wolf JP, Barbeau A (1979) Fatty acid profile of major lipid classes in plasma lipoproteins of patients with Friedreich's Ataxia. Demonstration of a low linoleic acid content most evident in the cholesteryl-ester fraction. Can J Neurol Sci 6:275-276.

Davignon J, Bouthillier D, Dufour R, Lussier-Cacan S (1983) Xanthomes et athérosclérose en présence de lipides sanguins normaux. Ann Méd Interne 134:483-491.

Davignon J, Sing CF, Lussier-Cacan S, Bouthillier D (1984) Xanthelasma, latent dyslipoproteinemia and atherosclerosis: contribution of apo E polymorphism. In: JL De Gennes, J Polonovski and R Paoletti (eds), Latent dyslipoproteinemia and atherosclerosis. Raven Press, New York, pp 213-223.

Eiberg H, Mohr J, Nielsen LS (1981) Linkage relationship between the locus for $\mathrm{C} 3$ and 47 polymorphic systems: confirmation of $\mathrm{C} 3$-Le linkage. (Abstract). Sixth Int Cong Human Genet, Jerusalem, p 147.

Elshourbagy N, McLean J, Mahley R, Taylor J (1984) Apolipoprotein E mRNA is relatively abundant in the brain, as well as in the liver and other tissues of marmosets and rats. Proceedings of the American Society of Biological Chemists, St Louis, MO, June 3 to 7, 1984.

Fredrickson DS, Goldstein JL, Brown MS (1978) The familial hyperlipoproteinemias. In: The metabolic basis of inherited disease. JB Stanbury, JB Wyngaarden and DS Fredrickson (eds). McGrawHill, New York, pp 604-655.

Ghiselli G, Gregg RE, Zech LA, Schaefer EJ, Brewer HB Jr (1982a) Phenotype study of apolipoprotein $\mathrm{E}$ isoforms in hyperlipoproteinemic patients. Lancet 2:405-407.
Ghiselli G, Schaefer EJ, Zech LA, Gregg LE, Brewer HB Jr (1982b) Increased prevalence of apolipoprotein $\mathrm{E} 4$ in type $\mathrm{V}$ hyperlipoproteinemia. J Clin Invest 70:474-477.

Gregg RE, Zech LA, Schaefer EJ, Brewer HB Jr (1981) Type III hyperlipoproteinemia: defective metabolism of an abnormal lipoprotein E. Science 211:584-585.

Gregg RE, Ghiselli G, Brewer HB Jr (1983) Apolipoprotein E: Bethesda: a new variant of apolipoprotein E associated with type III hyperlipoproteinemia. J Clin Endocrinol Metab 57:969-974.

Huang YS, Nestruck AC, Barbeau A. Bouchard JP, Davignon J (1978) Plasma lipids and lipoproteins in Friedreich's Ataxia and familial spastic ataxia - evidence for an abnormal composition of high density lipoproteins. Can J Neurol Sci 5:149-156.

Huang YS, Marcel YL, Vezina C, Barbeau A, Davignon J (1980) Lecithin-cholesterol acyltransferase activity and fatty acid composition of erythrocyte phospholipids in Friedreich's Ataxia. Can J Neurol Sci 7:429-434.

Mahley RW, Innerarity TL (1983) Lipoprotein receptors and cholesterol homeostasis. Biochim Biophys Acta 737:197-222.

Manual of Laboratory Operations, Lipid Research Clinics Program (1974). US Dept of HEW, Publication no: (NIH) 75-628, pp 1-81.

McLean JW, Elshourbagy NA, Chang DJ, Mahley RW, Taylor JM (1983) Heterozygosity within the E3 genotype of human apolipoprotein $\mathrm{E}$ as determined by nucleotide sequence analysis. Arteriosclerosis 3:514a.

Menzel HJ, Kladetsky RG, Assmann G (1983) Apolipoprotein E polymorphism and coronary artery disease. Arteriosclerosis 3:310-322.

Milne RW, Douste-Blazy Ph, Marcel YL, Retegui L (1981) Characterization of monoclonal antibodies against human apolipoprotein $\mathrm{E}$. J Clin Invest 68:111-117.

Olaisen B, Teisberg P, Gedde-Dahl T Jr (1982) The locus for apolipoprotein $\mathrm{E}$ (apo $\mathrm{E}$ ) is linked to the complement component $\mathrm{C} 3$ (C3) locus on chromosome 19 in man. Hum Genet 62:233-236.

Pourcher E, Barbeau A (1980) Field testing of an ataxia scoring and staging system. Can J Neurol Sci 7:339-344.

Rall SC Jr, Weisgraber KH. Innerarity TL, Mahley RW (1983) Identical structural and receptor binding defects in apolipoprotein E2 in hypo-, normo- and hypercholesterolemic dysbetalipoproteinemia. J Clin Invest 71:1023-1031.

Rall SC Jr, Weisgraber KH, Innerarity TL, Mahley RW (1984) Structure and function of apolipoprotein E: existence of multiple E2 alleles in type III hyperlipoproteinemia. In: Latent dyslipoproteinemias and atherosclerosis. JL de Gennes, J Polonovski and R Paoletti (eds). Raven Press, New York, pp 157-163.

Roheim PS, Carey M, Forte T, Vega GL (1979) Apolipoproteins in human cerebrospinal fluid. Proc Natl Acad Sci USA 76:4646-4649.

Sampson EJ, Demers LM, Krieg AF (1975) Faster enzymatic procedure for serum triglycerides. Clin Chem 21:1983-1985.

Schneider WJ, Kovanen PT, Brown MS, Goldstein JL, Utermann G, Weber W, Havel RJ, Kotite L. Kane JP, Innerarity TL, Mahley RW (1981) Familial dysbetalipoproteinemia. Abnormal binding of mutant apolipoprotein $E$ to low density lipoprotein receptors of human fibroblasts and membranes from liver and adrenals of rats, rabbits and cows. J Clin Invest 68:1075-1085.

Utermann G, Pruin N, Steinmetz A (1979) Polymorphism of apolipoprotein E - III Effect of a single polymorphic gene locus on plasma lipid levels in man. Clin Genet 15:63-72.

Utermann G, Steinmetz A, Weber W (1982) Genetic control of human apolipoprotein $\mathrm{E}$ polymorphism: comparison of one- and twodimensional techniques of isoprotein analysis. Hum Genet 60:344-351.

Warnick GR, Mayfield C. Albers JJ, Hazzard WR (1979) Gel isoelectric focusing method for specific diagnosis of familial hyperlipoproteinemia type III. Clin Chem 25:279-284.

Weisgraber KH, Rall SC, Mahley RW (198I) Human E apoprotein heterogeneity. Cysteine-arginine interchanges in the amino acid sequence of the apo $\mathrm{E}$ isoform. J Biol Chem 256:9077-9083.

Zannis VI, Breslow JL (1981) Human very low density lipoprotein apolipoprotein $\mathrm{E}$ isoprotein polymorphism is explained by genetic variation and post-translational modification. Biochemistry 20: 1033-1041 